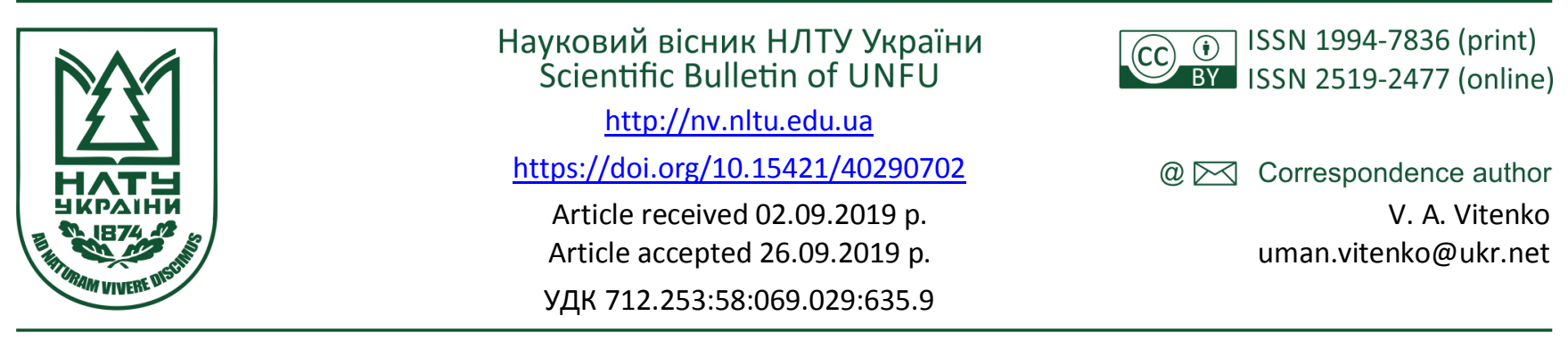

В. А. Вітенко, О. М. Баюра, І. В. Козаченко

Уманський наџіональний університет садівництва, м. Умань, Украйна

\title{
МЕТОДИКА КОМПЛЕКСНОГО ОЦІНЮВАННЯ СТАНУ ДЕРЕВНИХ РОСЛИН НА ПРИКЛАДІ ДЕКОРАТИВНИХ ФОРМ MORUS ALBA L.
}

На підставі опрацювання літературних джерел досліджено особливості оцінювання зовнішнього стану деревних рослин, що ростуть у різноманітних дендропарках і лісопарках. Виявлено, що сучасні способи та методи оцінки повною мірою не відображають стан даних рослин. Виділено окрему категорію деревних насаджень, котрі ростуть на різноманітних природоохоронних територіях. Оцінка стану цієї категорії рослин дає змогу розробити комплекс робіт з їх догляду, особливо вікових дерев. Відзначено, що окрім оцінювання стану асиміляційного апарату рослин, потрібно проводити загальне оцінювання стану стовбура та скелетних гілок. За результатами досліджень запропоновано до практичного використання методику комплексного оцінювання стану деревних рослин на прикладі $M$. alba та іiі декоративних форм, що базується на проведенні естетичної, морфологічної, біоекологічної та декоративної оцінки. Сума їх балів у цілому, занесена до відповідної формули, дає достовірну загальну оцінки стану деревних рослин. Проведено модифікацію 4-бальної шкали естетичної оцінки стану деревних насаджень у 6-бальну. За цією шкалою естетичність декоративних форм M. alba оцінено як добра та задовільна. За біоекологічною шкалою стан деревних рослин, що ростуть у Національному дендропарку "Софіївка" НАН України, оцінено в 1-2 бали, а за шкалою декоративності - в 3-4 бали. Встановлено, що в Національному дендропарку "Софіївка" НАН України зростає шість декоративних форм M. alba, які мають розкидисту, плакучу, пірамідальну, кулясту та звивисту форму крони. Для збереження естетичності деревних насаджень 7-го та 28-го кварталів дендропарку "Софіївка" потребують поступової заміни, шляхом підсаджування біля них молодих рослин форми M. a. 'Globosa' та M. a. 'Pendula'. За проведеною комплексною оцінкою стану деревних насаджень (на прикладі декоративних форм $M$. alba) у цьому дендропарку оцінено як добрий, а декоративність, як достатня. Ця методика комплексного оцінювання стану деревних рослин може широко застосовуватись для розроблення заходів із догляду за ними та прогнозування їх потенційного віку і вчасної заміни.

Ключові слова: комплексна оцінка стану деревних насаджень; морфологічна; естетична; біоекологічна; декоративна оцінка; декоративні форми M. alba.

Вступ. Деревні та кущові рослини відіграють велику роль у створенні сприятливих умов для життедіяльності людей в умовах інтенсивної урбанізації. Окрему категорію деревних насаджень складають інтродуковані рослини, які ростуть в історичних, старовинних парках та інших природоохоронних територіях. Від оцінки їх стану залежить комплекс робіт з догляду за ними. Особливо це стосується вікових рослин, що є головною окрасою окремих дендропарків, лісопарків, масивів чи відкритих ділянок. Зважаючи на це, актуальним питанням $є$ розроблення методики комплексного оцінювання стану деревних рослин в різних насадженнях, що дасть змогу проводити кваліфікований догляд за ними та підвищити тривалість життя.

Мета досліджень - розробити методику комплексного оцінювання стану деревних рослин у різних насадженнях на підставі спостереження за декоративними формами Morus alba.

Об'єкт дослідження - загальний стан декоративних форм Morus alba, котрі ростуть у різних кварталах На-

ціонального дендропарку "Софіївка" НАН України.

Методи дослідження. Біометричну оцінку декоративних форм M. alba проводили 3 урахуванням таких параметрів: висота рослин, діаметр стовбура на висоті 1,3 м визначали мірною лінійкою; діаметр окремих дерев з великою кількістю розгалужень поблизу зони кореневої шийки; діаметр крони (захід-схід $\rightarrow$ північ-південь $\uparrow$.

Вік рослин оцінювали за методикою В. А. Фролової (1994) у таких групах: 1 бал - молоді (М) рослини (дерева $з$ неповністю розвиненими кронами, які не досягли розмірів дорослих рослин); 2 бали - дорослі (Д) рослини (повністю сформовані рослини звичної для виду та форми величини); 3 бали - старі (C) рослини (дерева 3 явними ознаками старіння).

Морфологічну оцінку проводили для визначення ступеня щільності і форми крони деревних рослин. Форму крони визначали візуально, шляхом зіставлення 3 типовими природними формами (кулястою, плакучою, пірамідальною тощо). Щільність крони оцінювали

Інформація про авторів:

Вітенко Володимир Анатолійович, канд. біол. наук, доцент, кафедра лісового господарства. Email: uman.vitenko@ukr.net

Баюра Олександр Михайлович, канд. с.-г. наук, доцент, кафедра лісового господарства. Email: sasha-uman@ukr.net

Козаченко Ірина Володимирівна, канд. с.-г. наук, доцент, кафедра лісового господарства. Email: kozachenko_irina79@ukr.net

Цитування за ДСту: Вітенко В. А., Баюра О. М., Козаченко І. В. Методика комплексного оцінювання стану деревних рослин на прикладі декоративних форм Morus alba L. Науковий вісник НЛтУ України. 2019, т. 29, № 7. С. 13-16.

Citation APA: Vitenko, V. A., Bayra, O. M., \& Kozachenko, I. V. (2019). Methodology for the Comprehensive Assessment of the State of Decorative Plants on the Example of Decorative Forms of Morus alba L. Scientific Bulletin of UNFU, 29(7), 13-16. https://doi.org/10.15421/40290702 
візуально: 1 бал - щільна крона (просвіти менше 25 \%), 2 бали - середньої щільності (25-50\%), 3 бали - малощільна (більше $50 \%$ ).

Біоекологічну оцінку, метою якої $є$ визначення загального стану дерев, проводили за 3-бальною шкалою О. І. Гур'євої (2008), де: 1 бал (добра) - здорові рослини, але $з$ неправильно розвиненою кроною, без істотних пошкоджень; 2 бали (задовільна) - здорові рослини, але 3 неправильно розвиненою кроною, що мають пошкодження і дупла; 3 (незадовільна) - рослини з неправильно розвиненою, ослабленою, що має істотні пошкодження, які є загрозою їхньому життю, кроною.

Декоративність рослин оцінювали за 5-бальною шкалою О. А. Калініченка (2003), де: 5 балів - декоративність негативна (зовнішній вигляд рослин явно зменшує їхню загальну привабливість); 4 бали - нульова (декоративні якості непомітні, рослини не мають своєї виразності на загальному фоні насаджень); 3 бали - незначна (декоративні якості помітні, але невиразні, тому не дуже підвищують декоративність рослин); 2 бали - достатня (декоративні якості виразні, рослини добре виділяються на загальному фоні насаджень); 1 бал - висока (декоративні якості надають рослинам значної привабливості, зумовлюють у масового спостерігача почуття естетичного задоволення).

Результати дослідження та їх обговорення. Свої шкали оцінки стану деревних насаджень розробили: О. А. Калініченко (2003), С. І. Кузнецов (1998), О. І. Гур'єва (2008) та В. А. Фролова (1994).

На нашу думку, шкала С. І. Кузнецов (1998) може широко використовуватись для оцінювання загального стану молодих деревних насаджень. Головним показником оцінки стану рослин у цій шкалі є стан асиміляційного апарату рослин, від життєздатності якого залежить їх ріст та розвиток. Під час оцінювання вікових дерев, окрім оцінювання стану асиміляційного апарату рослин, потрібно визначити стан стовбура та скелетних гілок, адже досліджувана деревна рослина чи тип насадження може мати механічні чи інші пошкодження стовбура, а листкова поверхня буде повноцінною.

Чотирибальну шкалу оцінки естетичного стану деревних рослин В. А. Фролової (1994) було модифіковано тому, що в ній окремо не враховано естетичні якості вічнозелених рослин, які восени скидають хвою та листопадних рослин, здатних зберігати листя до наступної весни.

Зважаючи на це, запропоновано до використання таку 6-бальну шкалу оцінки естетичного стану деревних рослин, де: 1 бал-вічнозелені рослини, що зростають в чітко виділеному типі садово-паркових насаджень (ТСПН), де виконують свої функції; пропорційно розвинені, проявляють естетичні якості, відповідають їх виду і даній фенофазі, сухі гілки в кроні відсутні, або трапляються в невеликій кількості, виникли внаслідок природних ростових процесів; механічні пошкодження стовбура і гілок не завдають шкоди зовнішньому вигляду рослин; видимі ознаки пошкодження хворобами відсутні, видимі пошкодження шкідниками не викликають негативних емоцій у спостерігача; 2 бали - рослини, які зберігають листя до весни і ростуть у чітко виділеному типі садово-паркових насаджень (ТСПН), де виконують свої функції; пропорційно розвинені, проявляють естетичні якості, відповідають їх виду і даній фенофазі, сухі гілки у кроні відсутні, або трапляються в невеликій кількості, виникли внаслідок природних ростових про- цесів; механічні пошкодження стовбура і гілок не завдають шкоди зовнішньому вигляду рослин; видимі ознаки пошкодження хворобами відсутні, видимі пошкодження шкідниками не викликають негативних емоцій у спостерігача; 3 бали - рослини, які зростають в чітко виділеному типі садово-паркових насаджень (ТСПН), де виконують свої функції; пропорційно розвинені, проявляють естетичні якості, відповідають їх виду і даній фенофазі; сухі гілки в кроні відсутні, або трапляються в невеликій кількості, виникли внаслідок природних ростових процесів; механічні пошкодження стовбура і гілок не завдають шкоди зовнішньому вигляду рослин; видимі ознаки пошкодження хворобами відсутні, видимі пошкодження шкідниками не викликають негативних емоцій у спостерігача; 4 бали - рослини наділені якостями високо естетичних рослин, але спостерігаються перші ознаки зниження їх естетичних якостей. Поблизу рослин наявні фактори, здатні негативно вплинути на їх естетичний стан впродовж найближчих 13 років; 5 балів - рослини, котрі не виконують своїх функцій у насадженні, ТСПН не проглядаються, є відхилення в розвиткові: нахил стовбура, асиметричність крони, кількість сухих гілок більше $30 \%$, механічні пошкодження стовбура і крони, видимі сліди пошкодження шкідниками і хворобами; 6 балів- рослини, котрі повністю втрачають свої естетичні якості, відновлення яких неможливе.

Запропонована методика комплексного оцінювання стану деревних рослин на прикладі M. alba та іiі декоративних форм базується на проведенні естетичної, морфологічної, біоекологічної та декоративної оцінки (рисунок).

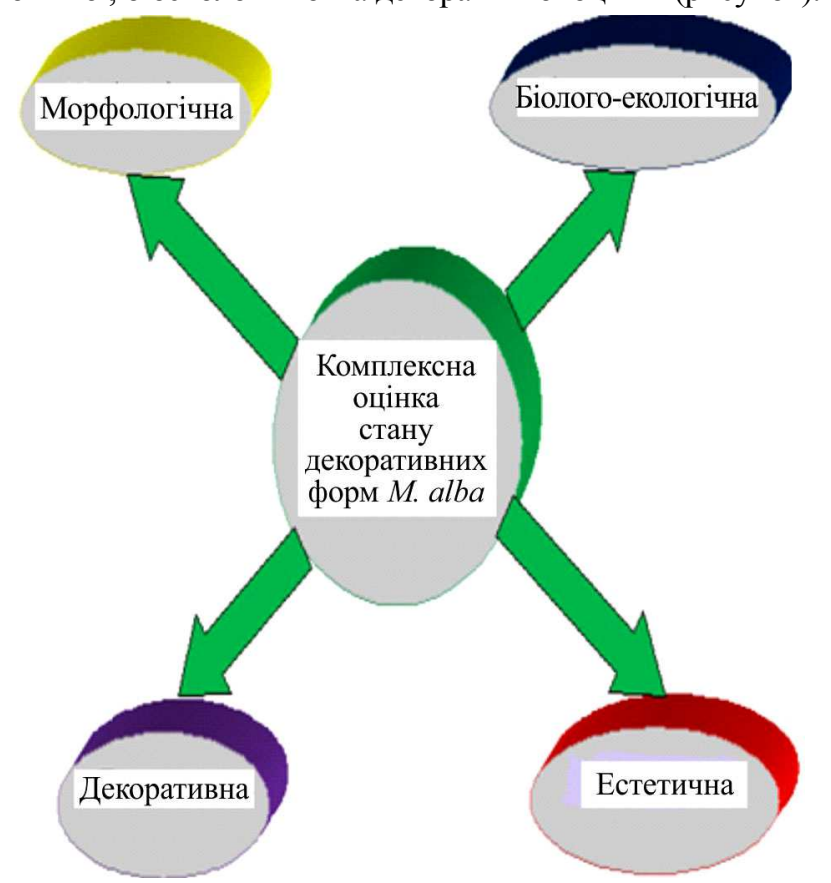

Рисунок. Складові комплексного оцінювання стану формового різноманіття M. alba в паркових насадженнях

Із суми цих чотирьох складових визначали комплексну оцінку стану формового різноманіття M. alba. Базовою територією для випробування цієї методики слугував Національний дендропарк "Софіївка" НАН України. За розробленою 6-бальною шкалою естетичності форми M. a. 'Globosa', що росте в 7 кварталі та M. a. 'Pendula' в 28 кварталі оцінено в 4 бали, а решта - в 3 бали. Дані $з$ морфологічної оцінки декоративних форм M. alba, які зростають у насадженнях Національного дендропарку 
"Софіївка" НАН України, наведено в табл. 1. Аналізуючи отримані дані, встановлено, що зростаюче в різних кварталах НДП "Софіївка" формове різноманіття Malba має плакучу, розкидисту, кулясту, звивисту та пірамідальну форму крони, а іiі щільність становить в середньому від 25 до $50 \%$ і оцінена в 1-2 бали.
Підсумки проведення біоекологічної оцінки декоративних форм $M$. alba в НДП "Софіївка" подано в табл. 2. Дані у цій таблиці показують, що більшість декоративних форм $M$. alba, які зростають в різних кварталах дендропарку, мають добрий та задовільний стан і достатню декоративність.

Табл. 1. Морфологічна оцінка декоративних форм M. alba в Національному дендропарку "Софіївка" НАН України

\begin{tabular}{|c|c|c|c|c|c|}
\hline \multirow{2}{*}{ № кварталу } & \multirow{2}{*}{ № 3/П } & \multirow{2}{*}{ Назва рослини } & \multirow{2}{*}{ Форма крони } & \multicolumn{2}{|c|}{ Щільність крони } \\
\hline & & & & $\%$ & бали \\
\hline 1 & 1 & M. alba 'Pendula' & плакуча & $<25$ & 1 \\
\hline 1 & $2-3$ & M. $a$. 'Pendula' & плакуча & $<25$ & 1 \\
\hline 1 & 4 & M. a. 'Pendula' & плакуча & $<25$ & 1 \\
\hline 1 & 5 & M. a. 'Macrophylla' & розкидиста & $<25$ & 1 \\
\hline 1 & 6 & M. a. 'Globosa' & куляста & $<25-50$ & 2 \\
\hline 1 & 7 & M. a. 'Contorta' & Звивиста & $<25-50$ & 2 \\
\hline 1 & 8 & M. a. 'Pyramidalis' & пірамідальна & $<25$ & 1 \\
\hline 2 & $9-10$ & M. a. 'Tatarica' & розкидиста & $<25-50$ & 2 \\
\hline 7 & $11-12$ & M. a. 'Globosa' & куляста & $<25-50$ & 2 \\
\hline 18 & 13 & M. a. 'Pendula' & плакуча & $<25$ & 1 \\
\hline 28 & $14-25$ & M. a. 'Pendula' & плакуча & $<25$ & 1 \\
\hline
\end{tabular}

Примітки: $<25 \%$ - щільна крона; $<25-50$ \% - середньої щільності.

Табл. 2. Біоекологічна та декоративна оцінка декоративних форм M. alba в Національному дендропарку "Софї̈вка" НАН України

\begin{tabular}{|c|c|c|c|c|}
\hline № кварталу & № $3 / \Pi$ & Назва рослини & Стан, бали & Декоративність, бали \\
\hline 1 & $1-4$ & M. alba 'Pendula' & 1 & 4 \\
\hline 1 & 5 & M. a. 'Macrophylla' & 1 & 4 \\
\hline 1 & 6 & M. a. 'Globosa' & 1 & 4 \\
\hline 1 & 7 & M. a. 'Contorta' & 1 & 4 \\
\hline 1 & 8 & M. a. 'Piramidalis' & 1 & 3 \\
\hline 2 & $9-10$ & M. a. 'Tatarica' & 1 & 3 \\
\hline 7 & 11 & M. a. 'Globosa' & 2 & 4 \\
\hline 7 & 12 & M. a. 'Globosa' & 1 & 4 \\
\hline 18 & 13 & M. a. 'Pendula' & 1 & 4 \\
\hline 28 & $14-19$ & M. a. 'Pendula' & 2 & 4 \\
\hline 28 & $20-21$ & M. a. 'Pendula' & 3 & 4 \\
\hline 28 & $22-23$ & M. a. 'Pendula' & 2 & 4 \\
\hline 28 & $24-25$ & Morus alba & 1 & 3 \\
\hline
\end{tabular}

Примітки: стан дерева: 1 бал - добрий; 2 бали - задовільний; 3 бали - незадовільний; декоративність: 3 бали - незначна; 4 бали - достатня.

Комплексну оцінку стану деревних рослин на прикладі декоративних форм $M$. alba проводять за формулою

$$
К О С Д Р=Б О+M O+E O+Д O,
$$

де: КОСДР - комплексна оцінка стану деревних рослин; БO - біоекологічна оцінка; $M O$ - морфологічна оцінка; $E O$ - естетична оцінка; ДО - декоративна оцінка.

Варто зазначити, що в разі отримання суми 7-8 балів стан деревних рослин оцінюють як добрий, за набраних 9-12 балів - задовільний, а 13 і більше балів - незадовільний.

Приклад. Під час комплексного оцінювання декоративної форми M. alba-M. a. 'Pendula', яка росте у 28 кварталі, отримуємо таке значення:

$$
\begin{aligned}
K O C= & Б O(2)+M O(2)+E O(4)+Д O(2)= \\
= & 9 \text { балів (добрий). }
\end{aligned}
$$

Аналізуючи отримані дані 3 комплексного оцінювання стану декоративних форм M. alba в Національному дендропарку "Софіївка" НАН України на підставі естетичної, дендрометричної, морфологічної та біоекологічної оцінки відзначаємо, що: в цьому дендропарку росте шість декоративних форм M. alba; потребують поступової заміни (шляхом посадки біля них молодих рослин) такі форми - M. a. 'Globosa', та M. a. 'Pendula'; для іiі декоративних форм характерні такі форми крони - розкидиста, плакуча, пірамідальна, куляста, звивиста; за щільністю крони досліджувані рослини можна поділити на середньощільні та щільні; загальний стан

насаджень (декоративних форм шовковиці білої) дендропарку добрий, а декоративність достатня.

\section{Висновки:}

1. Розроблено методику комплексного оцінювання деревних рослин на прикладі декоративних форм M. alba, що ростуть у НДП "Софіївка" НАН України.

2. Встановлено, що в НДП "Софіївка" НАН України росте шість декоративних форм M. alba. Потребують поступової заміни (шляхом посадки біля них молодих рослин) такі форми: $M$. . $a$. 'Globosa', та $M$. . $a$. 'Pendula'. Для декоративних форм $M$. alba характерні розкидиста, плакуча, пірамідальна, куляста, звивиста форми крони. За щільністю крони дані форми розділені на середньощільні та щільні.

3. За розробленою методикою стан декоративних форм $M$. $a l b a$, що ростуть в НДП "Софіївка", оцінено як задовільний (9 балів), а декоративність достатня.

\section{Перелік використаних джерел}

Frolova, V. A. (1994). Otcenka esteticheskikh dostoinstv prirodnykh landshaftov. (Ser. Geography). Vestnik $M G U, 5(2), 27-3$. [In Russian].

Gureva, E. I. (2008). Kompleksnaia otcenka drevesnykh porod na gorodskikh ulitcakh Voronezha. (Ser. Chemistry, biology). Vestnik $V G U, 1,86-92$. [In Russian].

Kalinichenko, O. A. (2003). Dekoratyvna dendrolohiia. Kiev: Higher school, 199 p. [In Ukrainian].

Kuznetsov, S. I. (1998). Ekolohichni peredumovy optymizatsii vulychnykh nasadzhen Kyieva. Pytannia bioindykatsii ta ekolohii, 3, 57-64. Zaporizhzhia: ZSU. [In Ukrainian]. 


\section{METHODOLOGY FOR THE COMPREHENSIVE ASSESSMENT OF THE STATE OF DECORATIVE PLANTS ON THE EXAMPLE OF DECORATIVE FORMS OF MORUS ALBA L.}

Based on the studying literary sources, the features of assessing the external state of woody plants growing in various arboretums and forest parks are studied. It was revealed that the existing methods and assessment methods did not fully reflect the state of these plants. A separate category of tree plantations that grow in various conservation areas has been identified. Assessment of the condition of this category of plants enables developing a set of work on their care, especially centuries-old trees. It is noted that in addition to assessing the state of the assimilation apparatus of plants, it is necessary to carry out general assessments of the state of the trunk and skeletal branches. As a result of the research, a methodology for a comprehensive assessment of the state of woody plants using $M$. alba and its decorative forms as an aesthetic, morphological, bioecological, and decorative assessment was proposed for practical use. The sum of their points as a whole, is entered in the corresponding formula, and gives a reliable overall assessment of the state of woody plants. The 4-point scale of aesthetic assessment of the state of tree plantings was modified to a 6-point scale. On this scale, the aesthetics of the decorative forms of $M$. alba was rated as good and satisfactory. According to the bioecological scale, the condition of woody plants growing in the National Arboretum "Sofiyivka" of the National Academy of Sciences of Ukraine was estimated at 1-2 points, and the decorative scale at 3-4 points. It is established that six decorative forms of $M$. alba, which have a spreading, weeping, pyramidal, spherical, and sinuous crown shape, grow in the Sofiyivka National Arboretum of the National Academy of Sciences of Ukraine. To preserve the aesthetics of the tree stands of the 7th and 28th quarters of Sofiyivka Arboretum, they need to be gradually replaced by replanting young plants of the form $M . a$. 'Globosa' and M. $a$. 'Pendula'. Based on the results of a comprehensive assessment of the state of tree plantations (using the example of decorative forms of $M$. alba) in this arboretum, it was rated as good, and decorativeness as sufficient. This technique of a comprehensive assessment of the state of woody plants can be widely used to develop measures for their care and predict their life expectancy and timely replacement.

Keywords: complex assessment of the state of tree plantations; morphological; aesthetic; bioecological; decorative evaluation; decorative forms of $M$. alba. 